\title{
Lack of Vitamin D and Autoimmune Diseases of the Thyroid - Evidences Based on Meta-Analysis
}

\author{
Geovana Batista Rubin'; Lucas Cândido Gonçalves²; Paulo Alex Neves da Silva'; Xisto Sena \\ Passos'; Antonio Márcio Teodoro Cordeiro Silva’3; Natália Menezes Silval \\ \lucascandidogoncalves46@gmail.com
}

1. Universidade Paulista - UNIP, Goiânia-GO

2. Universidade Federal de Goiás - UFG, Goiânia-GO

3. Pontifícia Universidade Católica de Goiás - PUC Goiás, Goiânia-GO.

Histórico do Artigo: 0 autor detém os direitos autorais deste artigo.

Recebido em: 01 de janeiro de 2021 Aceito em: 07 de junho de $2021 \quad$ Publicado em: 31 de dezembro de 2021

\begin{abstract}
To verify whether there is a difference between serum vitamin D averages in patients with Graves' disease and Hashimoto's thyroiditis, when compared with a group of healthy individuals. This is a systematic review and meta-analysis according to the PRISMA protocol. The test of difference of means with random effect and chisquare of heterogeneity was performed, considering an alpha $<0.05$ for acceptance of the hypotheses. The tests were performed using the STATA ${ }^{\circledR} 16.0$ software. There were differences between serum vitamin D averages: group with Graves' disease compared to healthy individuals (Mean $=10.06 ; 95 \% \mathrm{CI}=0.99-19.14$ ); Group with Hashimoto's disease compared to healthy individuals (Mean $=12.49 ; 95 \% \mathrm{CI}=5,9-19,79$ ); group of children with Hashimoto compared to healthy children, $($ Mean $=19.46 ; 95 \% \mathrm{CI}=10.25-28.68)$. The mean serum vitamin D levels were significantly higher in healthy individuals, demonstrating that the depletion of this nutrient may be related to the pathophysiological process of these diseases, taking into account the immunomodulatory function that this vitamin has.
\end{abstract}

Keywords: Hashimoto disease, Graves Disease, Vitamin D Deficiency, Thyroiditis.

\section{Carência de Vitamina D e Doenças Autoimunes da Tireóide - Evidências Baseadas em Metanálise}

Resumo: Verificar se há diferença entre médias séricas de vitamina D em portadores de doença de Graves e tireoidite de Hashimoto, quando comparados com um grupo de indivíduos sadios. Trata-se de uma revisão sistemática e metanálise de acordo com o protocolo PRISMA. Foi realizado o teste de diferença de médias com efeito aleatório e qui-quadrado de heterogeneidade, considerando um alfa $<0,05$ para aceitação das hipóteses. $0 \mathrm{~s}$ testes foram realizados com auxílio do software STATA ${ }^{\circledR} 16.0$. Houve diferenças entre as médias séricas de vitamina D: grupo com doença de Graves comparado a indivíduos saudáveis (Média =10,06; IC95\%=0,99-19,14); Grupo com doença de Hashimoto comparado a indivíduos saudáveis (Média = 12,49; IC95\%= 5,19-19,79); grupo de crianças com Hashimoto em comparação com crianças saudáveis, (Média = 19,46 (IC95\%=10,25-28,68). 0s níveis médios de vitamina D sérica foram significativamente maiores em indivíduos sadios, demonstrando que a depleção desse nutriente pode estar relacionada ao processo fisiopatológico dessas doenças, levando-se em consideração a função imunomoduladora que essa vitamina exerce.

Palavras-chave: Doença de Hashimoto, Doença de Graves, Deficiência de Vitamina D, Tireoidite. 


\section{Falta de Vitamina D y Enfermedades Autoinmunes de la Tiroides - Evidencias Basadas en Metanálisis}

Resumen: Verificar si existe diferencia entre los promedios séricos de vitamina D en pacientes con enfermedad de Graves y tiroiditis de Hashimoto, en comparación con un grupo de individuos sanos.Se trata de una revisión sistemática y metaanálisis según el protocolo PRISMA. Se realizó la prueba de diferencia de medias con efecto aleatorio y chi-cuadrado de heterogeneidad, considerando un alfa $<0,05$ para la aceptación de las hipótesis. Las pruebas se realizaron con el software STATA ${ }^{\circledR} 16.0$. Hubo una diferencia entre los promedios de vitamina D sérica: grupo con enfermedad de Graves en comparación con individuos sanos (Media = 10,06; IC 95\% = 0,99-19,14); Grupo con enfermedad de Hashimoto en comparación con individuos sanos (Media = 12,49; IC 95\% = 5,19-19,79); grupo de niños con Hashimoto en comparación con niños sanos, (Media = 19,46; IC 95\% = 10,25-28,68). Los niveles séricos promedio de vitamina D fueron significativamente mayores en individuos sanos, demostrando que el agotamiento de este nutriente puede estar relacionado con el proceso fisiopatológico de estas enfermedades, tomando en cuenta la función inmunomoduladora que tiene esta vitamina.

Palabras clave: Enfermedad de Hashimoto, Enfermedad de Graves, Deficiencia de Vitamina D, Tiroiditis.

\section{INTRODUCTION}

Autoimmune diseases are characterized by the absence of immunological tolerance, caused by the combination of environmental and genetic factors, however, the knowledge about the function of each of these susceptibility factors is not yet precise (MERRILL; MINUCCI, 2018; WEETMAN, 2003). They also involve phenotype factors, of which the main diseases they represent are Hashimoto's thyroiditis (HT) and Graves' disease (GD) (RAGUSA et al., 2019; LAZARUS; PARKES, 2002).

Autoimmune thyroid diseases are polygenic diseases, which result in the combination of genetic predisposition (specific thyroid genes and immunomodulators) and environmental stimuli (selenium, iodine, infections, stress, smoking, etc.) (KÖHLING et al., 2017; KLECHA et al. 2008). TH is a common autoimmune chronic disease of the thyroid gland, characterized by inflammation of the gland, development of diffuse goiter with elevated thyroid antibodies, which occurs through the infiltration of immune cells in the thyroid (DJUROVIC et al., 2018).

After invasion of the thyroid gland by lymphocytic cells, there is follicular atrophy and associated hyperemia of oncocytic metaplasia of the cell follicles, the atrophy of the thyroid tissue, occurs gradually, this leads to the development of hypothyroidism, even with normal thyroid activity (RYDZEWSKA et al., 2018; PEARCE et al., 2003). In GD there is a slight infiltration of lymphocytes, with the involvement of TCD4 + helper cells, known as T helper 2 (Th2), which stimulates the production of antibodies binding to thyroid stimulating hormone (TSH) receptors. Where, after binding to receptors, they induce cell growth, increasing their 
metabolism, causing hyperthyroidism, indicating a humoral immune response (SAWICKA et al., 2020; KLECHA et al., 2008).

Vitamin D is a fat-soluble molecule, has hormone-like effects and comes from the skin, in the form of cholecalciferol (vitamin D3) or acquired through diet in the form of ergocalciferol (vitamin D2) (TRIPKOVIC et al., 2012). Among its functions are the regulation of the metabolism of calcium and phosphorus and the maintenance of skeletal health, bones and parathyroid gland (DOBSON et al., 2017; DASTANI; RICHARDS, 2013).

Studies carried out in recent years report the extra skeletal effects of vitamin D, associated with the deficiency of the nutrient in question (KMIEC; SWORCZAK, 2015) and genetic variations, relating the impaired metabolism of this vitamin to several autoimmune diseases, including autoimmune disease thyroid (INOUE et al., 2014). With this, the present research is justified by the need to determine if there is a reduction of vitamin D in Individuals with GD and HT, due to the heterogeneity between previous research results (XU et al., 2018; KE et al., 2017; MA et al., 2015). Thus, the objective was to assess the difference between the mean serum vitamin D levels, in groups of individuals diagnosed with HT and GD, comparing them with individuals without the diseases.

\section{MATERIAL AND METHODS}

This study consisted of a systematic review and meta-analysis, adopting the descriptive aspect. Meta-analysis is a method of statistical study, applied to systematic review to combine data from studies, with the objective of obtaining results in the same measure and with greater reliability (XU et al., 2015).

After consulting the Health Sciences Descriptors (DeCS), the following descriptors were identified: Hashimoto's Disease, Graves' Disease and Vitamin D Deficiency. With the descriptors, articles published in the databases were accessed: Latin American Literature and Caribbean Health Sciences (LILACS), Scientific Electronic Library Online (SciEL0), Medical Literature Analysis and Retrieval System Online (MEDLINE) and PubMed, considering articles published from 2002 to 2020, giving preference to articles published in the last four years.

In LILACS, 20 references were found, which were printed, all with availability of the title, year and place of publication, others also provided the summary. In SciEL0 16 references were found and in PubMed 162 references. The repetitions and publications that were not related to the topic were excluded, resulting in 46 references, of which 19 contributed to the systematic 
Lack of Vitamin D and Autoimmune Diseases of the Thyroid - Evidences Based on MetaAnalysis

review and meta-analysis. For the descriptive aspect, bibliographic reviews were selected that described Graves' diseases and Hashimoto's thyroiditis.

Inclusion criteria were: case-control studies, articles describing thyroid diseases and the relationship of vitamin D with individuals with Hashimoto's thyroiditis and Graves' disease, articles that compared children with the same diseases were included. Articles published in English and Portuguese were considered. The exclusion criteria were: books, course completion papers, monographs, dissertations and articles not related to the theme (Figure 1).

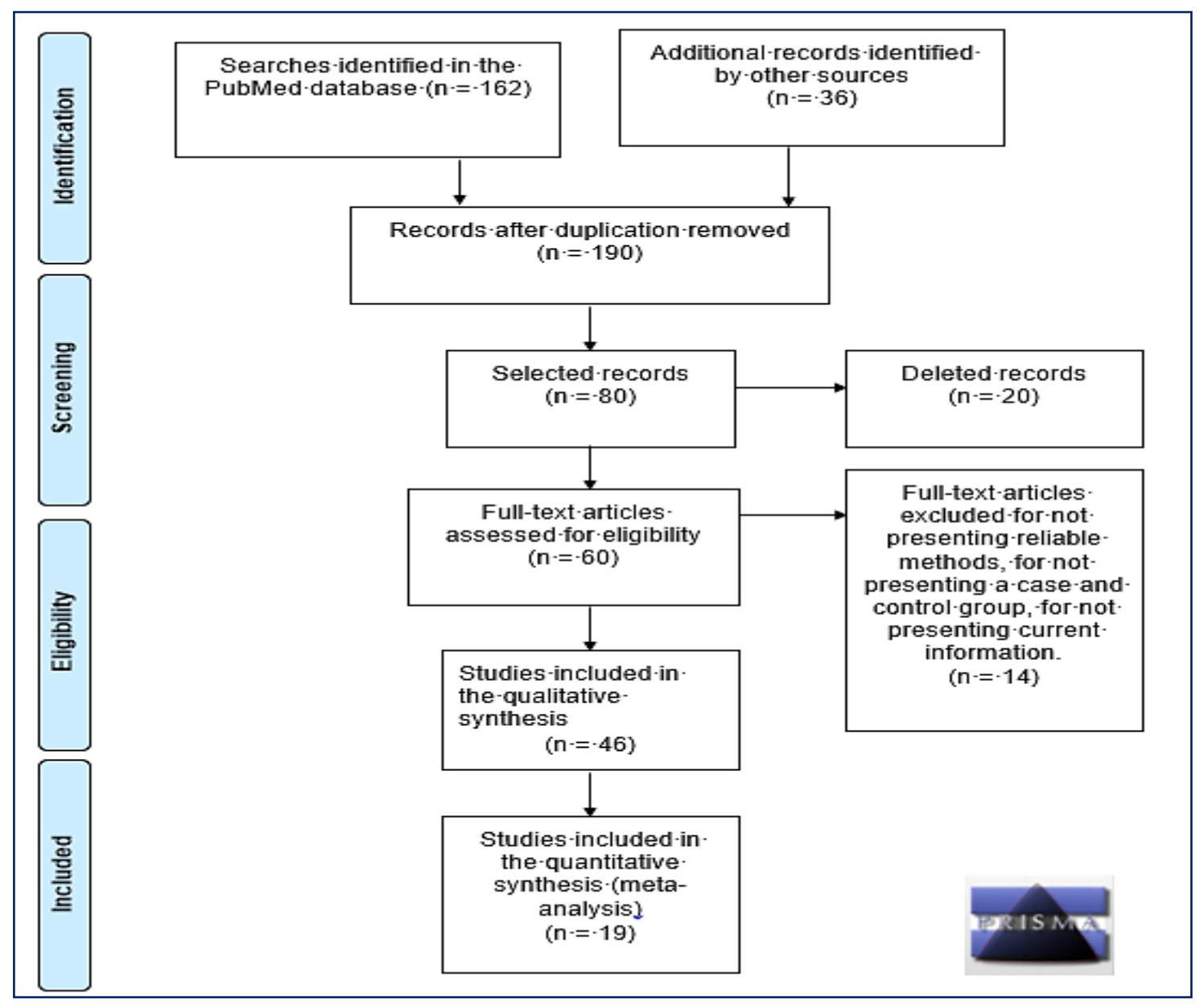

Figure 1. Flowchart: selection of articles used for systematic review and meta-analysis. Source: Authors, 2020.

The evaluation, extraction and tabulation of data were based on the PRISMA (Preferred Reporting Items for Systematic Reviews and Meta-Analyzes) instructions and recommendations (MOHER et al., 2009). Thus, the selected articles, for data extraction, were submitted to the evaluation of two reviewers and there were no disagreements regarding the interpretations. 
After selecting the articles according to the inclusion and exclusion criteria, the data of the 19 references were tabulated, relevant to the analysis of serum vitamin D levels in individuals with Graves' disease and Hashimoto's thyroiditis. Conversions of units of measurement referring to serum vitamin D, from $\mathrm{ng} / \mathrm{mL}$ to nmol / L, with the objective of obtaining results with greater reliability, were subsequently applied mean test of differences (MD) with randomized effect, the effect adopted, considered the difference between the results collected, as well as the diverse ethnicity and diverse methodologies. The chi-square test $\left(\chi^{2}\right)$ of heterogeneity was performed, considering an alpha $\leq 0.05$ for random or randomized effect. 0 n the other hand, if the alpha resulted in $>0.05$, the fixed effect would be adopted, that is, ignoring the existing heterogeneity, considering that the heterogeneity occurred by chance. The $\mathrm{I}^{2}$ test or the Higgins and Thompson test was also carried out, in order to confirm the heterogeneity between the studies, since the number of screened samples is small and the $\mathrm{X}^{2}$ test in these situations is not specific. Thus, the following interpretation was considered: $0 \%$ without heterogeneity, 25\% low heterogeneity, 50\% moderate heterogeneity and 75\% or more, high heterogeneity (HIGGINS et al., 2003; HIGGINS; THOMPSON, 2002). The risk of bias in the selected surveys was assessed using the Funnel Plot graph associated with the Egger and Begg tests. The verified hypothesis was: "There is a significant difference between the serum averages of vitamin D, when comparing groups with Graves and Hashimoto's disease with groups of individuals without the diseases" and if the diamond in the Forest Plot graph touched the null line, it would be considered the null hypothesis: "there is no difference between serum vitamin D averages between the groups compared". The statistical tests were performed with the aid of the STATA ${ }^{\circledR} 16.0$ Software.

\section{RESULTS AND DISCUSSION}

Data extraction resulted for Graves' disease: control group $(\mathrm{n}=3,174)$ and case group $(\mathrm{n}$ $=779)$, for Hashimoto's thyroiditis: control group $(n=1,317)$ and case group $(n=1,304)$ and Hashimoto's thyroiditis in children with a mean age of 12.15 years: control group $(n=221)$ and case group $(\mathrm{n}=236)$ (Table 1$)$.

The assessment of bias through the asymmetry in the Funnel Plot graph, pointed out a probable bias in the surveys carried out so far. The Begg and Egger tests pointed to adults with Hashimoto: Egger with $\mathrm{p}>[\mathrm{z}]=0.0001$ and Begg with $\mathrm{p}>[\mathrm{z}]=0.2105$; for adults with Graves' disease: Egger with $\mathrm{p}>[\mathrm{z}]=0.4776$ and Begg with $\mathrm{p}>[\mathrm{z}]=0.9170$; for children with Hashimoto: 
Lack of Vitamin D and Autoimmune Diseases of the Thyroid - Evidences Based on MetaAnalysis

Egger with $\mathrm{p}>[\mathrm{z}]=0.0030$ and Begg with $\mathrm{p}>[\mathrm{z}]=1.9633$. Despite the asymmetry of the surveys plotted on the Funnel plot graphs and the results of the Egger test point to a significant bias, the results with greater credibility were those of the Begg test, due to significant heterogeneity and the small number of surveys (Figure 2).

Table 1. Data containing serum vitamin D concentrations in the case and control groups.

Data - Vitamin D (nmol / L) Hashimoto

\begin{tabular}{|c|c|c|c|c|c|c|c|c|c|c|c|}
\hline Author, years & $\begin{array}{l}\text { Count } \\
\text { ries }\end{array}$ & $\mathrm{CN}$ & AC & SDC & DN & AD & $\begin{array}{l}\text { SD } \\
\text { D }\end{array}$ & DT & UM & $\begin{array}{l}\text { Gend } \\
\text { er }\end{array}$ & $\begin{array}{l}\text { A } \\
\text { A }\end{array}$ \\
\hline $\begin{array}{l}\text { Yasmeh et al., } \\
(2016)\end{array}$ & USA & 45 & $\begin{array}{l}71 . \\
7\end{array}$ & 21.0 & 60 & $\begin{array}{l}80.0 \\
7 \\
\end{array}$ & 19.4 & na & $\begin{array}{l}\mathrm{nmol} / \\
\mathrm{L}\end{array}$ & $f$ & $\begin{array}{l}47 \\
.5\end{array}$ \\
\hline Xu et al., (2018) & China & 200 & $\begin{array}{l}44 . \\
3\end{array}$ & 9.6 & 194 & 33.9 & 6.2 & Prot-binding & $\begin{array}{l}\mathrm{nmol} / \\
\mathrm{L}\end{array}$ & $\mathrm{f} / \mathrm{m}$ & $\begin{array}{l}49 \\
.4\end{array}$ \\
\hline $\begin{array}{l}\text { Maciejewski et } \\
\text { al., (2015) }\end{array}$ & Poland & 32 & $\begin{array}{l}30 . \\
3\end{array}$ & 19.4 & 62 & 20.0 & 12.6 & EAI & $\begin{array}{l}\mathrm{nmol} / \\
\mathrm{L}\end{array}$ & $f / m$ & $\begin{array}{l}49 \\
.1\end{array}$ \\
\hline $\begin{array}{l}\text { Mansournia et } \\
\text { al., (2014) }\end{array}$ & Iran & 46 & $\begin{array}{l}63 . \\
4 \\
\end{array}$ & 44.9 & 41 & 41.3 & 31.4 & ELISA & $\begin{array}{l}\mathrm{nmol} / \\
\mathrm{L}\end{array}$ & $\mathrm{f} / \mathrm{m}$ & $\begin{array}{l}42 \\
.3 \\
\end{array}$ \\
\hline $\operatorname{Kim}_{(2016)}$ et al., & Korea & 407 & $\begin{array}{l}99 . \\
6\end{array}$ & 53.7 & 221 & 92.1 & 57.4 & E170 & $\begin{array}{l}\mathrm{nmol} / \\
\mathrm{L}\end{array}$ & $\mathrm{f} / \mathrm{m}$ & $\begin{array}{l}41 \\
.9\end{array}$ \\
\hline $\begin{array}{l}\text { Bozkurt et al., } \\
(2013)\end{array}$ & Turkey & 180 & $\begin{array}{l}40 . \\
0\end{array}$ & 17.6 & 180 & 34.0 & 15.3 & ELISA & $\begin{array}{l}\mathrm{nmol} / \\
\mathrm{L}\end{array}$ & $\mathrm{f} / \mathrm{m}$ & $\begin{array}{l}42 \\
.3\end{array}$ \\
\hline 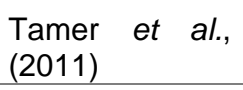 & Turkey & 162 & $\begin{array}{l}76 . \\
9\end{array}$ & 66.2 & 161 & 42.3 & 27 & 25(OH)2D3 & $\begin{array}{l}\mathrm{nmol} / \\
\mathrm{L}\end{array}$ & $\mathrm{f} / \mathrm{m}$ & $\begin{array}{l}35 \\
.4\end{array}$ \\
\hline Ma et al., (2015) & China & 70 & $\begin{array}{l}41 . \\
3\end{array}$ & 14.4 & 70 & 31 & 11.1 & ECLA & $\begin{array}{l}\mathrm{nmol} / \\
\mathrm{L}\end{array}$ & $f / m$ & $\begin{array}{l}40 \\
.1 \\
\end{array}$ \\
\hline Ke et al., (2017) & China & 51 & $\begin{array}{l}83 . \\
4\end{array}$ & 6.2 & 61 & 55.2 & 3.8 & ECLA & $\begin{array}{l}\mathrm{nmol} / \\
\mathrm{L}\end{array}$ & $\mathrm{f} / \mathrm{m}$ & $\begin{array}{l}40 \\
.8\end{array}$ \\
\hline $\begin{array}{l}\text { Unal et al., } \\
(2014)\end{array}$ & Turkey & 124 & $\begin{array}{l}58 . \\
4\end{array}$ & 40.0 & 254 & 50.4 & 26.2 & Archit. 11000 & $\begin{array}{l}\mathrm{nmol} / \\
\mathrm{L}\end{array}$ & $\mathrm{nc}$ & $\begin{array}{l}44 \\
.6 \\
\end{array}$ \\
\hline Combined & & $\begin{array}{l}131 \\
7\end{array}$ & $\begin{array}{l}60 . \\
9\end{array}$ & $\begin{array}{l}29.3 \\
5\end{array}$ & $\begin{array}{l}130 \\
4\end{array}$ & $\begin{array}{l}48.0 \\
5\end{array}$ & $\begin{array}{l}21.0 \\
8\end{array}$ & & $p$-value $<0$ & . & $97 \%$ \\
\hline
\end{tabular}

Data - vitamin D - children (nmol / L) Hashimoto

\begin{tabular}{|c|c|c|c|c|c|c|c|c|c|c|c|}
\hline Author, years & $\begin{array}{l}\text { Count } \\
\text { ries }\end{array}$ & $\mathrm{CN}$ & $A C$ & SDC & DN & AD & $\begin{array}{l}\text { SD } \\
\text { D }\end{array}$ & DT & UM & $\begin{array}{l}\text { Gend } \\
\text { er }\end{array}$ & $\begin{array}{l}\mathbf{A} \\
\mathbf{A}\end{array}$ \\
\hline $\begin{array}{l}\text { Sonmezgoz et } \\
\text { al., (2016) }\end{array}$ & China & 68 & $\begin{array}{l}62 . \\
6\end{array}$ & 24.4 & 68 & 43.6 & 23.9 & C-501/E-601 & $\begin{array}{l}\mathrm{nmol} / \\
\mathrm{L}\end{array}$ & $\mathrm{f} / \mathrm{m}$ & $\begin{array}{l}12 \\
.1\end{array}$ \\
\hline $\begin{array}{l}\text { Çamurdan et } \\
\text { al., (2012) }\end{array}$ & Turkey & 74 & $\begin{array}{l}57 . \\
9\end{array}$ & 19. & 78 & 31.2 & 11.5 & HPLC & $\begin{array}{l}\mathrm{nmol} / \\
\mathrm{L}\end{array}$ & $\mathrm{nc}$ & 12 \\
\hline $\begin{array}{l}\text { Evliyaoglu } \\
\text { al., (2015) }\end{array}$ & Turkey & 79 & $\begin{array}{l}54 . \\
5\end{array}$ & 25.6 & 90 & 43.3 & 30.2 & Archit. i2000sr & $\begin{array}{l}\mathrm{nmol} / \\
\mathrm{L}\end{array}$ & $\mathrm{f} / \mathrm{m}$ & $\begin{array}{l}12 \\
.3\end{array}$ \\
\hline Combined & & 221 & $\begin{array}{l}58 . \\
3\end{array}$ & 23.2 & 236 & 39.4 & 21.8 & & $p$-value $=$ & $.007 ; I^{2}$ & $30 \%$ \\
\hline
\end{tabular}

Data - vitamin D (nmol / L) Graves' Disease

\begin{tabular}{|c|c|c|c|c|c|c|c|c|c|c|c|}
\hline Author, years & Countries & $\mathrm{CN}$ & AC & $\begin{array}{l}\text { SD } \\
\text { C }\end{array}$ & DN & AD & $\begin{array}{l}\text { SD } \\
\text { D }\end{array}$ & DT & UM & $\begin{array}{l}\text { Gend } \\
\text { er }\end{array}$ & AA \\
\hline $\begin{array}{l}\text { Yasuda et al., } \\
(2012)\end{array}$ & Japan & 46 & $\begin{array}{l}44 . \\
4\end{array}$ & 10.6 & 26 & 37.4 & 12.7 & $\begin{array}{l}\text { Prot- } \\
\text { binding }\end{array}$ & $\begin{array}{l}\mathrm{nmol} \\
/ \mathrm{L}\end{array}$ & $f$ & 37.3 \\
\hline
\end{tabular}




\begin{tabular}{|c|c|c|c|c|c|c|c|c|c|c|c|}
\hline $\begin{array}{l}\text { Yasuda et al., } \\
(2013)\end{array}$ & Japan & 49 & $\begin{array}{l}48 . \\
3\end{array}$ & 13.7 & 36 & 37.6 & 7.5 & $\begin{array}{l}\text { Prot- } \\
\text { binding }\end{array}$ & $\begin{array}{l}\mathrm{nmol} \\
\mathrm{L}\end{array}$ & $f$ & 37.8 \\
\hline $\begin{array}{l}\text { Planck et al., } \\
(2017)\end{array}$ & Sweden & $\begin{array}{l}230 \\
5\end{array}$ & $\begin{array}{l}87 . \\
2\end{array}$ & 27.6 & 292 & 55 & 23.2 & na & $\begin{array}{l}\mathrm{nmol} \\
/ \mathrm{L}\end{array}$ & $\mathrm{f} / \mathrm{m}$ & 45.5 \\
\hline $\begin{array}{l}\text { Unal et al., } \\
(2014)\end{array}$ & Turkey & 124 & $\begin{array}{l}58 . \\
4\end{array}$ & 40.0 & 27 & 38.7 & 22.3 & $\begin{array}{l}\text { Archit. } \\
\text { i1000 }\end{array}$ & $\begin{array}{l}\text { nmol } \\
/ L\end{array}$ & $\mathrm{nc}$ & 44.6 \\
\hline $\begin{array}{l}\text { Mangaraj } \\
\text { al., (2019) }\end{array}$ & India & 42 & $\begin{array}{l}61 . \\
9\end{array}$ & 32.3 & 84 & 49.9 & 23.2 & ECLIA & $\begin{array}{l}\mathrm{nmol} \\
/ \mathrm{L}\end{array}$ & $f / m$ & 35 \\
\hline $\begin{array}{l}\text { Jyotsna et al., } \\
\text { (2012) }\end{array}$ & India & 80 & $\begin{array}{l}28 . \\
5\end{array}$ & $\begin{array}{l}18.3 \\
2\end{array}$ & 80 & $\begin{array}{l}32.9 \\
3\end{array}$ & $\begin{array}{l}16.2 \\
2\end{array}$ & RIA & $\begin{array}{l}\mathrm{nmol} \\
/ \mathrm{L}\end{array}$ & $\mathrm{f} / \mathrm{m}$ & 36.3 \\
\hline $\begin{array}{l}\mathrm{Ke} \text { et al., } \\
(2017)\end{array}$ & China & 51 & $\begin{array}{l}83 . \\
4\end{array}$ & 6.24 & 51 & 81.7 & 5.6 & ECLA & $\begin{array}{l}\mathrm{nmol} \\
\mathrm{L}\end{array}$ & $f / m$ & 39.7 \\
\hline $\operatorname{Kim}_{(2016)}$ et al., & Korea & 407 & $\begin{array}{l}99 . \\
6\end{array}$ & 53.7 & 148 & 98.1 & 54.9 & E170 & $\begin{array}{l}\mathrm{nmol} \\
\mathrm{L}\end{array}$ & $\mathrm{f} / \mathrm{m}$ & 41.9 \\
\hline $\begin{array}{l}\text { Zhang et al., } \\
(2015)\end{array}$ & China & 70 & $\begin{array}{l}60 . \\
6\end{array}$ & 10.9 & 35 & 49.2 & 8.2 & ELISA & $\begin{array}{l}\mathrm{nmol} \\
\mathrm{L}\end{array}$ & $\mathrm{f} / \mathrm{m}$ & 31.7 \\
\hline Combined & & $\begin{array}{l}317 \\
4\end{array}$ & $\begin{array}{l}63 . \\
6\end{array}$ & 23.7 & 779 & 53.4 & $\begin{array}{l}19.3 \\
3\end{array}$ & & $p$-valu & $=0.00$ & $\left.\right|^{2}=97 \%$ \\
\hline
\end{tabular}

Caption: Meaning of abbreviations: f: Female gender, m: male gender, na: not applicable, CN: Control number, $\mathrm{AC}$ : Average control, SDC: Standard deviation Control, DN: Disease number, AD: Average disease, SDD: Standard Deviation Disease, UM: Unit of Measure, AA: Average Age, DT: Dosing Technique.

Source: Authors, 2020.

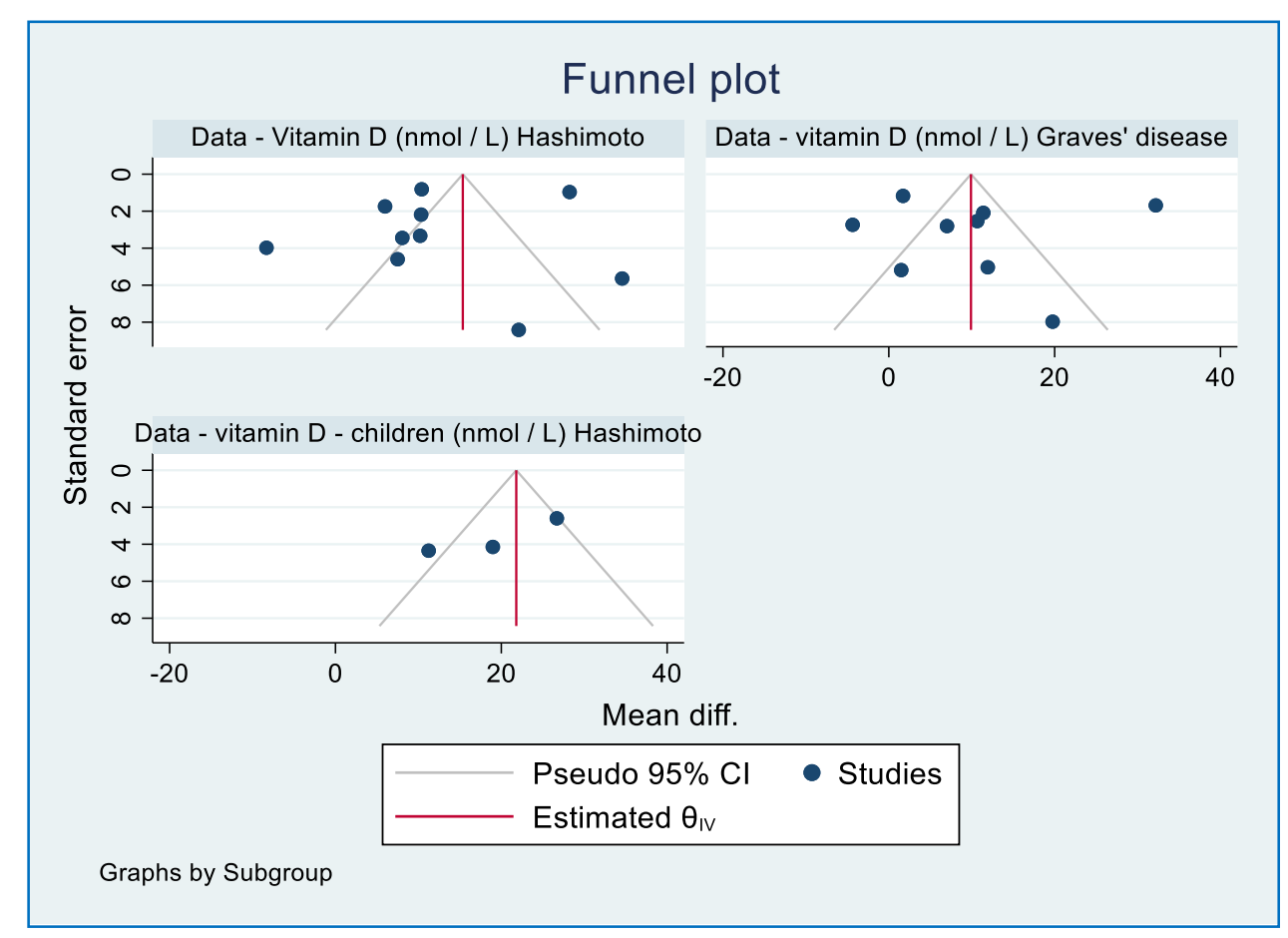

Figure 2. Funnel plot graphs for bias assessment, distribution of research results.

Source: Authors, 2020. 
Lack of Vitamin D and Autoimmune Diseases of the Thyroid - Evidences Based on MetaAnalysis

The pertinent results to the serum comparison of vitamin D, between individuals with Graves' disease and healthy individuals, showed a significant difference from the mean serum vitamin D (MD = 10.06; 95\% CI = 0.99-19.14), indicating a mean serum nutrient equal to $10.06 \mathrm{nmol}$ / L more in the control group when compared to patients with Graves' disease. The confidence interval (CI) of the diamond, which represents the difference between means (MD), does not touch the null line, confirming the significance of the result and rejecting the null hypothesis. The results of the study by Ke et al., (2017) and Planck et al., (2017), obtained greater weight, however, of the two mentioned, only that of Planck et al., (2017), showed a significant difference. The result of the chi-square of heterogeneity with $\mathrm{p}=0.00$ and the $\mathrm{I}^{2}=97 \%$, justify the application of the randomized effect (Figure 3).

Of the data collected, $90 \%$ obtained a statistically significant difference, between serum vitamin D averages, when comparing the group of individuals with Hashimoto's thyroiditis with the group of healthy individuals. The 10\% insignificance refers to the results of Kim, (2016), this can be seen in the graph, where the confidence interval of the study crosses the null line. The test showed that serum vitamin D is on average $12.49 \mathrm{nmol} / \mathrm{L}$ more in healthy individuals, with $(95 \% \mathrm{CI}=5.19$ to 19.79$)$. The heterogeneity test was significant with $\mathrm{p}=0.00$, where in combination with $\mathrm{I}^{2}=97 \%$, they demonstrate assertiveness in the adopted random effect (Figure 3).

In $100 \%$ of the studies plotted, referring to analyzes with data from children, with proof of Hashimoto's thyroiditis diagnosis, significance was evidenced in relation to the difference between serum vitamin D means, $\mathrm{MD}=19.46(95 \% \mathrm{CI}=10.25-28.68)$, the result in question points out a difference between the averages, where the group of healthy children emerged in serum mean, with $19.46 \mathrm{nmol} / \mathrm{L}$ more of the nutrient. The heterogeneity test was significant with $\mathrm{p}=$ 0.01 and the $\mathrm{I}^{2}=80 \%$, the results together demonstrate assertiveness in choosing the randomized effect (Figure 3). 


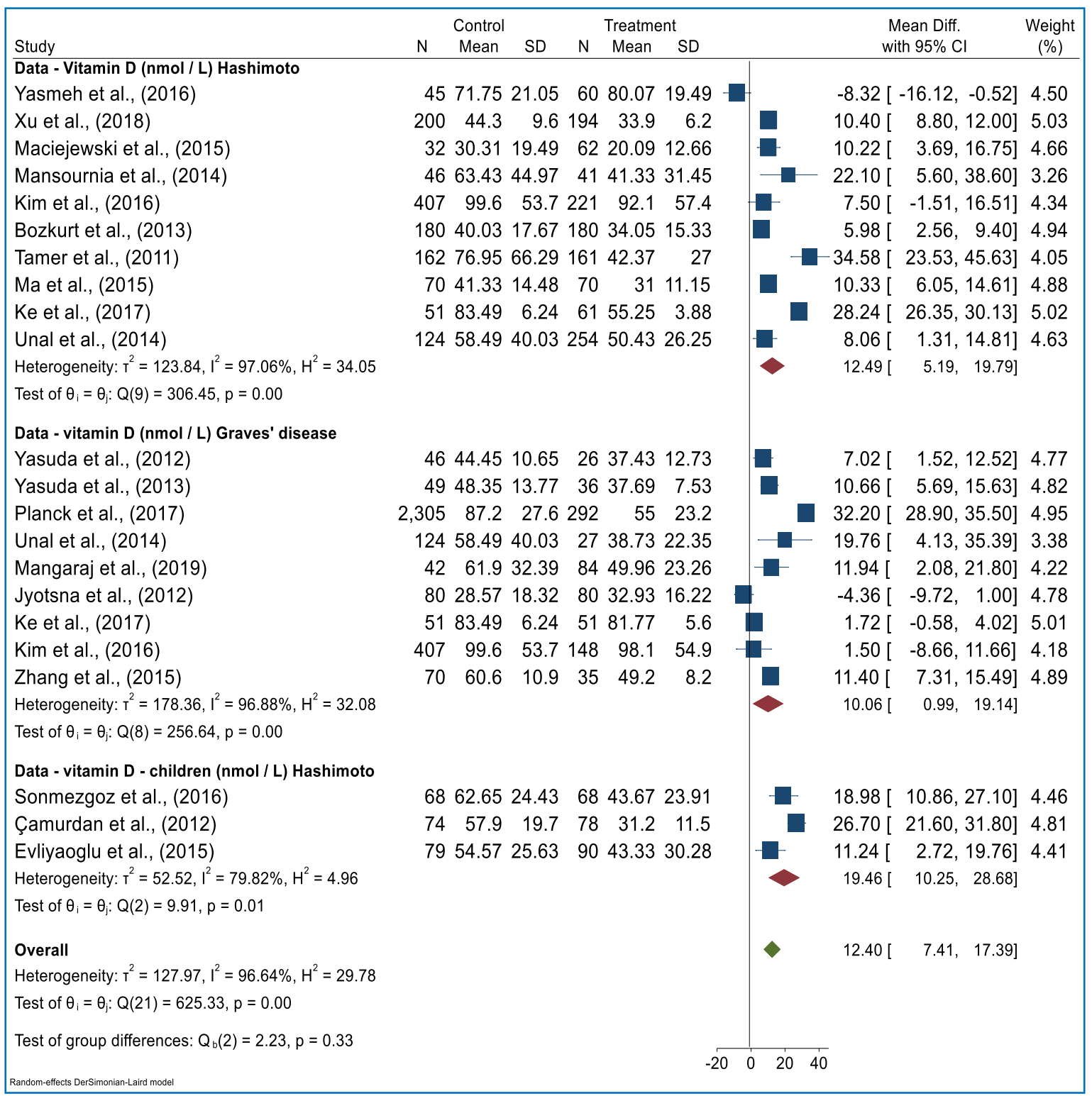

Figure 3. Forest Plot graphs: Comparison between serum vitamin D levels. Source: Authors, 2020.

The relationship between autoimmune diseases and low serum vitamin D levels has been commonly accepted and studied by researchers. Ma et al., (2015), observed that the deficiency of $25(\mathrm{OH})$ D or vitamin D, was significantly prevalent in patients who had some autoimmune thyroid disease, when compared to healthy individuals. Bellastella et al., (2015), concluded that the serum vitamin D level was reduced in patients with autoimmune diseases.

In the present study, serum vitamin D levels were lower in individuals diagnosed with Hashimoto's thyroiditis and Graves' disease, when compared to healthy individuals. The prevalence of vitamin D deficiency is present in patients with autoimmune thyroid diseases, which suggests that vitamin D may be related to the pathophysiological process of the diseases 
Lack of Vitamin D and Autoimmune Diseases of the Thyroid - Evidences Based on MetaAnalysis

mentioned.

It is believed that the development of autoimmune thyroid diseases is correlated with the disproportion of T helper 1 (Thl) and T helper 2 (Th2) helper cells. Hashimoto's thyroiditis occurs when there is an increase in the proportion of Thl cells, which lead to the secretion of gamma interferon (IFN-y) (KARANIKAS et al., 2005), whereas patients with Graves' disease have an increase in the proportion of cells Th2 that secrete interleukin-4 (IL-4) (TSATSOULIS, 2006). Studies relate Thl7 cytokine secretion to the development of autoimmune thyroid diseases (LI et al., 2013).

Vitamin D performs an important function in the regulation of Th1, Th2 and Th17 cells, consequently, regulation in the secretion of cytokines IFN-4, IL-4 and IL-17 (JOSHI et al., 2011). The low serum level of vitamin D is also related to the increase in anti-TSH receptor antibodies (TRAb) in the serious disease (ZHANG et al., 2015), these antibodies lead to the development of hyperthyroidism.

Vitamin D exerts its biological effects through the mediation of the vitamin D receptor (VDR, vitamin D receptor), which is found in almost all human cells and participates in direct and indirect forms of the regulation of the immune system. It plays an important role as an immunomodulatory factor, which influences the proliferation and differentiation processes of immune cells. It plays an important role in several cells, including dendritic cells, as it modifies their differentiation and maturation process, reducing the class that presents a major class II histocompatibility complex (MHC II), and also reduces co-stimulating proteins (CD40, CD80, CD86), present in the membrane of dendritic cells, in addition to making changes in the production pattern of cytokines. Due to these changes that occur in dendritic cells, vitamin D indirectly interferes with the activation of lymphocytes, and regularizes Th2 cells and directly inhibits the proliferation of T lymphocytes, especially Thl cells. In this way, it results in a change in the proportions of Thl and Th2 cells in anti-inflammatory processes and promotes weakening of Th2 lymphocytes, which are essential for the inflammatory process of autoimmune thyroid diseases.

The analyzed case-control studies showed a high prevalence of vitamin D deficiency in children with Hashimoto's thyroiditis, with an average age of 12.15 years. These children, mostly are female, also verified the incidence by other authors. It is suggested that estrogen receptors act to reduce immune surveillance, which may justify the higher occurrence in women (LEE $e t$ al., 2015). 
Vitamin D supplementation can reduce morbidity or alleviate the effects of manifestations in animals with autoimmunity (ETTEN-VAN et al., 2003). Results are also described, where vitamin D supplementation can benefit humans with autoimmune diseases (PIERROT-DESEILLIGNY et al., 2012) and that childhood supplementation potentiates these benefits, reducing the risk of developing thyroid disease (ZIPITIS; AKOBENG, 2008), demonstrating the need of the nutritionist associated with the endocrinologist, in the treatment and supplementation of vitamin D.

\section{CONCLUSION}

Based on the results obtained, patients with autoimmune thyroid diseases have serum vitamin D deficiency when compared to healthy individuals. The present research showed vitamin D deficiency in patients with Graves' disease and Hashimoto's thyroiditis, regardless of age. The lack of this nutrient may be related to the pathogenesis of these diseases, as an immunomodulator. However, more research is needed to confirm this hypothesis.

\section{ACKNOWLEDGMENT}

Sra. Geovana Batista Rubin - First author, contributed to the bibliographic survey and described on the subject, also contributed with the methodology of the article and discussion.

Dr. Antonio Márcio Teodoro Cordeiro Silva and Sr. Lucas Cândido Gonçalves - Both statisticians, two statisticians needed to follow the PRISMA protocol, performed and described the results. They also described the methodology of applied statistics. Lucas is a master's student at the Federal University of Goiás and Antonio Márcio is a professor at PUC Goiás, both with experience in meta-analysis.

Dr. Xisto Sena Passos and Me. Paulo Alex Neves da Silva - Applied methodology and translation into English. They also held much of the discussion and conclusion. Xisto is a professor of methodology at the Universidade Paulista de Goiânia and Paulo has training and knowledge in immunology, thus, they were of great importance and contributions.

Ma. Natália Menezes Silva - Work supervisor, followed the whole process, guiding and making the necessary corrections in the descriptive aspect. The advisor is a nutritionist and therefore played a key role. He was also responsible for placing the manuscript in the RIC rules. 


\section{REFERÊNCIAS BIBLIOGRÁFICAS}

BELLASTELLA, G. et al. Vitamin D and autoimmunity: What happens in autoimmune polyendocrine syndromes? Journal of Endocrinological Investigation. v. 32, n. 6, p. 629-633, 2015.

B0ZKURT, N. C. et al. The association Between Severity of Vitamin D deficiency and Hashimoto's Thyroiditis. Endocrine Practice. v. 19, n. 3, p. 479-484, 2013.

CAMURDAN, 0. M. et al. Vitamin D status in Children with Hashimoto Thyroiditis. Journal of pediatric endocrinology \& metabolismo. v. 25, n. 5/6, p. 467-470, 2012.

DASTANI, Z.; LI, R.; RICHARDS, B. Genetic regulation of vitamin D levels. Calcifield Tissue International. v. 92, n. 2, p. 106-117, 2013.

DOBSON, R. et al. Vitamin D supplementation. Pract Neurol., v. 18, n. 1, p. 35-42, 2017.

DJUROVIC, M. et al. Cognitive functioning and quality of life in patients with Hashimoto thyroiditis on long-term levothyroxine replacement. Endocrine. v. 62, n. 1, p. 136-143, 2018.

ETTEN-VAN, E. et al. Combination of a 1,25-dihydroxyvitamin D3 analog and a bisphosphonate prevents experimental autoimmune encephalomyelitis and preserves bone. Bone. v. 32, n. 4, p. 397-404, 2003.

EVLIYA0ĞLU, 0. et al. Vitamin D deficiency and Hashimoto's Thyroiditis in Children and Adolescents: A critical Vitamin D level for this Association? Journal of clinical research in pediatric endocrinology. v. 7, n. 2, p. 128-133, 2015.

HIGGINS, J. P. T. et al. Measuring inconsistency in meta-analyses. Educ debate. v. 327, n. s/n, p. 557-560, 2003.

HIGGINS, J. P. T; THOMPSON, S.G. Quantifying heterogeneity in a meta-analysis. Stat Med. v. 21, n. s/n, p. 1539-1558, 2002.

INOUE, N. et al. The functional polymorphisms of VDR, GC and CYP2R1 are involved in the pathogenesis of autoimmune thyroid diseases. Clinical \& Experimental Immunology. v. 178, n. 2, p. 262-269, 2014.

JOSHI, S. et al. 1,25-Dihydroxyvitamin D3 Ameliorates Thl7 Autoimmunity via Transcriptional Modulation of Interleukin-17A. Molecular and Cellular Biology. v. 31, n. 17, p. 3653-3669, 2011.

JYOTSNA, V. P. et al. Bone mineral density in patients of Graves disease pre- \& posttreatment in a predominantly vitamin D deficient population. Indian Journal of Medical Research. v. 135, n. 1, p. 36-41, 2012.

KARANIKAS, G. et al. Relation of anti-TP0 autoantibody titre and T-lymphocyte cytokine production patterns in Hashimoto's thyroiditis. Clinical Endocrinology. v. 63, n. 2, p. 191-196, 2005.

KE, W. et al. 25-hydroxyvitamin D serum level in Hashimoto's thyroiditis, but not Graves' disease is relatively deficient. Endocrine Journal. v. 64, n. 6, p. 581-587, 2007.

KIM, D. Low vitamin D status is associated with hypothyroid hashimoto's thyroiditis. Hormones. v. 15. n. 3, p. 385393, 2016.

KÖHLING, H. L. et al. The microbiota and autoimmunity: their role in thyroid autoimune diseases. Clinical Immunology, v. 183, p. 63-74, 2017.

KLECHA, A. J. et al. Immune-endocrine interactions in autoimmune thyroid diseases. Neuroimmunomodulation. v. 15, n. 1, p. 68-75, 2008.

KMIEĆ, P.; SWORCZAK, K. Vitamin D in Thyroid Disorders. Experimental and Clinical Endocrinology \& Diabetes. v. 123 , n. 7, p. 386-393, 2015. 
LAZARUS, J. H.; PARKES, A. B.; PREMAWARDHANA, L. D. K. E. Postpartum thyroiditis. Autoimmunity. v. 35, n. 3, p. 169173, 2002.

LEE, H. J. et al. Immunogenetics of autoimmune thyroid diseases: A comprehensive review. Journal of Autoimmunity. v. 64, p. 82-90, 2015.

LI, D. et al. Thl7 cell plays a role in the pathogenesis of Hashimoto's thyroiditis in patients. Clinical Immunology. v. 149, n. 3, p. 411-420, 2013.

MA, J. et al. Lower serum 25-hydroxy Vitamin D level is associated with 3 types of autoimmune thyroid diseases. Medicine. v. 94, n. 39, p. 1-7, 2015.

MACIEJEWSKI, A. et al. Assessment of Vitamin D levels in Autoimmune Thyroiditis Patients and a Control Group in Polish Population. Advances in clinical and experimental medicine. v. 24, n. 5, p. 801-806, 2015.

MANSOURNIA, N. et al. The association between serum 250HD levels and hypothyroid Hashimoto's Thyroiditis. Journal of endocrinological investigation. v. 37, n. 5, p. 473-476, 2014.

MANGARAJ, S. et al. Evaluation of Vitamin D Status and its Impacto n Thyroid Related Parameters in New 0nset Graves Disease A cross Sctional 0bservational Study. Indian Journal of Endocrinology and Metabolism, v. 23, n. 1, p. 35-39, 2019.

MERRIL, S. J.; MINUCCI, S. B. Thyroid Autoimmunity: An Interplay of Factors. Vitamins and Hormones, v. 106, n. s/n, p. 129-145, 2018.

MOHER, D. et al. Preferred Reporting Items for Systematic Reviews and Meta-Analyses: The PRISMA Statement. Plos Medicine, v. 6, n. 7, p. 1-7, 2009.

PEARCE, E. N.; FARWELL, A. P.; BRAVERMAN, L. E. Thyroiditis. The New England Journal of Medicine. v. 348, n. 26, p. $2646-2655,2003$.

PIERROT-DESEILLIGNY, C. et al. Relationship between 25-0H-D serum level and relapse rate in multiple sclerosis patients before and after vitamin D supplementation. Therapeutic Advances Neurological Disorders, v. 5, n. 4, p. 187-198, 2012.

PLANCK, T. et al. Vitamin D in Graves Disease: Levels Correlation with Laboratory and Clinical Parameters, and Genetics. European Thyroid Journal, v. 7, n. 1, p. 27-33, 2017.

RAGUSA, F. et al. Hashimotos' Thyroiditis: epidemiology, pathogenesis, clinic and therapy. Best Practice \& Research Clinical Endocrinology \& Metabolism, v. 33, n. 6, p. 101367, 2019.

ROEVER, L. et al. Methodology to perform and interpret a systematic review and individual meta-analysis of participants' data. Revista Sociedade Brasileira de Clínica Médica, v. 17, n. 1, p. 47-52, 2019.

RYDZEWSKA, M. et al. Role of the T and B lymphocytes in pathogenesis of autoimmune thyroid diseases. Thyroid Research, v. 11, n. 2, p. 1-11, 2018.

SAWICKA, B. et al. Analysis of Polymorphisms rs7093069-IL-2RA, rs7138803-FAIM2, and rs1748033-PADI4 in the Group of Adolescents With Autoimmune Thyroid Diseases. Frontiers in Endocrinology, v. 11, n. 544658, p. 1-7, 2020.

SÖNMEZGÖZ, E. et al. Hypovitaminosis D in Children With Hashimoto's Thyroiditis. Revista Médica de Chile, v. 144, n. 5, p. 611-616, 2016.

TAMER, G. et al. Relative Vitamin D insufficiency in Hashimoto's Thyroiditis. Journal Thyroid, v. 21, n. 8, p. 891-896, 2011.

TRIPKOVIC, L. et al. Comparison of vitamin D2 and vitamin D3 supplementation in raising serum 25-hydroxyvitamin D status: a systematic review and meta-analysis. The American Journal of Clinical Nutrition, v. 74, n. 224, p. 1357$1364,2012$. 
Lack of Vitamin D and Autoimmune Diseases of the Thyroid - Evidences Based on MetaAnalysis

TSATSOULIS, A. The role of stress in the clinical expression of thyroid autoimmunity. Annal of The New York Academy of Sciences, v. 1088, n. 1, p. 382-395, 2006.

UNAL, A. D. et al. Vitamin D deficiency is related to thyroid antibodies in autoimune thyroiditis. Clinical Immunology, v. 39, n. 4, p. 493-497, 2014.

WEETMAN, A.P. Autoimmune thyroid disease: Propagation and progression. European Journal of Endocrinology, v. 148. n. 1, p. 1-9, 2003.

YASMEH, J. et al. Hashimoto Thyroiditis not associated with vitamin D deficiency. Endocrine Practice, v. 22, n. 7, p. 809-813, 2016.

YASUDA, T. et al. Serum vitamin D levels are decreased and associated with thyroid volume in female patients with newly onset Graves disease. Endocrine, v. 42, n. 3, p. 739-741, 2012.

YASUDA, T. et al. Serum vitamin D levels are decresead in patients without remission of Graves disease. Endocrine, v. 43, n. 1, p. $230-232,2013$.

XU, J. et al. Low Vitamin D levels are associeted with cognitive impairment in patients with Hashimoto Thyroiditis. BMC Endocrine Disorders, v. 18, n. 1, p. 1-6, 2018.

ZHANG, H.; LIANG, L.; XIE, Z. Low Vitamin D status is associated with increased thyrotropin-receptor antibody titer in graves' disease. Endocrine Practice. v. 21, n. 3, p. 258-263, 2015.

ZIPITIS, C. S.; AKOBENG, A. K. Vitamin D supplementation in early childhood and risk of type 1 diabetes: a systematic review and meta-analysis. Archives of Disease in Childhood. v. 93, n. 6, p. 512-517, 2008. 